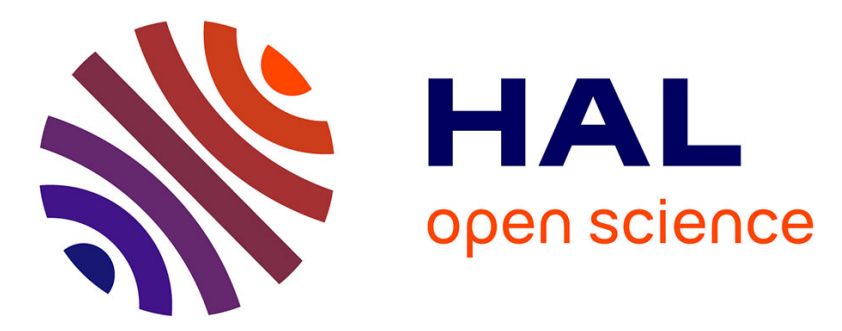

\title{
Estrogen receptor subtype-specific effects on markers of bone homeostasis
}

T. Hertrampf, B. Schleipen, M. Velders, U. Laudenbach, K.H. Fritzemeier, P. Diel

\section{- To cite this version:}

T. Hertrampf, B. Schleipen, M. Velders, U. Laudenbach, K.H. Fritzemeier, et al.. Estrogen receptor subtype-specific effects on markers of bone homeostasis. Molecular and Cellular Endocrinology, 2008, 291 (1-2), pp.104. 10.1016/j.mce.2008.03.003 . hal-00532015

\section{HAL Id: hal-00532015 https://hal.science/hal-00532015}

Submitted on 4 Nov 2010

HAL is a multi-disciplinary open access archive for the deposit and dissemination of scientific research documents, whether they are published or not. The documents may come from teaching and research institutions in France or abroad, or from public or private research centers.
L'archive ouverte pluridisciplinaire HAL, est destinée au dépôt et à la diffusion de documents scientifiques de niveau recherche, publiés ou non, émanant des établissements d'enseignement et de recherche français ou étrangers, des laboratoires publics ou privés. 


\section{Accepted Manuscript}

Title: Estrogen receptor subtype-specific effects on markers of bone homeostasis

Authors: T. Hertrampf, B. Schleipen, M. Velders, U. Laudenbach, K.H. Fritzemeier, P. Diel

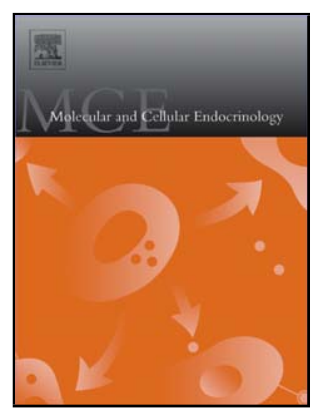

PII:

S0303-7207(08)00119-6

DOI: doi:10.1016/j.mce.2008.03.003

Reference: MCE 6844

To appear in: $\quad$ Molecular and Cellular Endocrinology

Received date: $\quad 30-1-2008$

Revised date: $\quad 10-3-2008$

Accepted date: $\quad 10-3-2008$

Please cite this article as: Hertrampf, T., Schleipen, B., Velders, M., Laudenbach, U., Fritzemeier, K.H., Diel, P., Estrogen receptor subtype-specific effects on markers of bone homeostasis, Molecular and Cellular Endocrinology (2007), doi:10.1016/j.mce.2008.03.003

This is a PDF file of an unedited manuscript that has been accepted for publication. As a service to our customers we are providing this early version of the manuscript. The manuscript will undergo copyediting, typesetting, and review of the resulting proof before it is published in its final form. Please note that during the production process errors may be discovered which could affect the content, and all legal disclaimers that apply to the journal pertain. 
Estrogen receptor subtype-specific effects on markers of bone homeostasis

Hertrampf $\mathrm{T}^{1}$, Schleipen $\mathrm{B}^{1}$, Velders $\mathrm{M}^{1}$, Laudenbach $\mathrm{U}^{1}$, Fritzemeier $\mathrm{KH}^{2}$, Diel $\mathrm{P}^{1}$

${ }^{1}$ Institut für Kreislaufforschung und Sportmedizin, Abt. molekulare und zelluläre Sportmedizin, DSHS Köln

${ }^{2}$ Bayer Schering Pharma AG Berlin

Corresponding Address:

Dr. Torsten Hertrampf

Dept. Molecular and Cellular Sports Medicine

Deutsche Sporthochschule Köln

Carl-Diem-Weg 6

50933 Köln

Germany

Phone: +49-221-4982-5860

Fax: $+49-221-4982-8370$

e-mail: hertrampf@dshs-koeln.de 


\section{Abstract}

To further elucidate the processes involved in the physiology of bone-protection by estrogens, ovariectomized (OVX) rats were treated subcutaneously with $17 \beta-$ estradiol, the ER $\alpha$-specific agonist (16 $\alpha$-LE2) and the ER $\beta$-specific agonist (8$\beta-V E 2)$. OVX and intact animals served as controls. Biomarkers of bone-formation (osteocalcin (OC), osteopontin (OPN)) and bone-resorption (telopeptides of collagen type I (CTx), pyridinoline cross-links (Pyd)) were quantified. Bone mineral density was measured by computed tomography.

OVX-induced bone loss could be antagonized by subcutaneous administration of $17 \beta$-estradiol and $16 \alpha$-LE2. Serum levels of CTx, OC and OPN were significantly elevated in OVX compared to intact animals and reduced by $17 \beta$-estradiol and $16 \alpha-$ LE2. Treatment of OVX rats with $8 \beta-\mathrm{VE} 2$ did not affect BMD or bone-marker serum levels.

Taken together, the complex expression pattern of bone-markers in OVX rats following subcutaneous administration of ER subtype-specific agonists indicates that $17 \beta$-estradiol exerts its bone-protective effects by modulating the activity of osteoclasts and osteoblasts via ERa. 
Key words: estrogen receptor alpha, estrogen receptor beta, estrogen receptor subtype-specific agonists, biochemical bone markers, bone mineral density, estrogens 


\section{Abbreviations:}

16 $\alpha$-LE2 ERa-specific agonist

8ß-VE2 ERß-specific agonist

BALP bone specific alkaline phosphatase

b. wt. body weight

CTx C-terminal telopeptide

d day

DAl Daidzein

Dpd desoxipyridinoline cross-links

$E_{2} \quad 17 \beta$-estradiol/ group substituted with a low dose of $E_{2}$

ELISA enzyme linked immunosorbent assay

ER estrogen receptor

ERa estrogen receptor alpha

ER $\beta \quad$ estrogen receptor beta

Fas Faslodex

GEN: $\quad$ Genistein

HRT hormone replacement therapy

IL-6 interleukin-6

IDD isoflavone depleted diet

NTx N-terminal telopeptide

OC osteocalcin

OPN osteopontin

OPG osteoprotegerin

pQCT peripheral quantitative computed tomography

Pyd pyridinoline cross-links 
RAL raloxifene

RANK receptor activator of nuclear factor kappaB

RANKL receptor activator of nuclear factor kappaB ligand

S.c. subcutaneous

SERM selective estrogen receptor modulator

TAM tamoxifen

TRAP5b tartrate-resistant acid phosphatase isoform $5 b$ 


\section{Introduction}

In the estrogen-deficient state, such as menopause, the balance between bone resorption and bone formation shifts towards increased levels of bone resorption.

Hormone replacement therapy (HRT), if started soon after the onset of menopause, is effective for reducing or reversing postmenopausal bone loss (Lindsay et al. 1976, Fitzpatrick 2006). Besides its use for treatment of postmenopausal symptoms, potential benefits of HRT include the prevention of cardiovascular disease and dementia (Stevenson 2004). SERMs like Tamoxifen (TAM) and Raloxifene (RAL) are known to preserve bone mineral density (BMD) and act in breast tissue as estrogen antagonists (Diez-Perez 2006). Unfortunately, in postmenopausal women who take TAM the risk of developing endometrial cancer increases (Jordan 2008). Hence, an urgent need exists to develop new pharmaceutical agents that mediate the boneprotective effects of estrogens without increasing the risk of developing breast and endometrial cancer.

The anabolic activity of osteoblasts and the pathways through which these bone cells activate osteoclasts are affected by estrogens (Girasole et al. 1992) and selective estrogen receptor (ER) modulators (SERMs) (Taranta et al. 2002). Moreover, estrogens have the ability to decrease the differentiation of osteoclast progenitor cells (Sato et al. 2001, Sorensen et al. 2006) and to inhibit the bone-resorbing activity of terminally differentiated osteoclasts (Lerner 2006). Since both ER subtypes (ERa and ER $\beta$ ) are expressed in bone tissue (Bland 2000, Bord et al. 2001, Krassas \& Papadopoulou 2001) it can be assumed that estrogens and SERMs mediate their bone-remodelling effects by directly binding to ERs expressed within bone cells (Bryant et al. 1999, Diez 2000). Moreover, it has to be taken into consideration that skeletal effects of estrogen are not only mediated by classical but also by non- 
classical ER pathways (Syed et al. 2005). Although bone cells express both ER subtypes, in vitro studies (Zaman et al. 2000) and those conducted in vivo with ER knockout mice (Windahl et al. 1999, Lee et al. 2003) or ER subtype-specific ligands (Hertrampf et al. 2007) have shown that ERa but not ERß is required for boneprotection by estrogens.

It is well described that bone homeostasis depends on the balance of two different processes: formation and mineralization of bone matrix through osteoblasts and removal of mineralized bone by osteoclasts (Buckwalter et al. 1996, Hadjidakis \& Androulakis 2006). Trabecular rather than cortical bone is more frequently remodelled, which explains why metabolic bone diseases such as osteoporosis are mainly observed in bones with comparatively large amounts of trabecular bone (Lerner 2006). Activation and induction of differentiation of osteoclast progenitor cells by osteoblasts is mediated through the receptor activator of nuclear factor kappaB (RANK)/RANK ligand (RANKL)/osteoprotegerin (OPG) signalling pathway (Lerner 2006, Blair et al. 2007). In this context, it was shown that inactivation of RANKL by a specific antibody leads to profound and prolonged inhibition of bone-resorption in postmenopausal women (Hamdy 2007). Furthermore, ERa but not ER $\beta$ is known to be involved in the regulation of the ratio of OPG and RANKL (Lindberg et al. 2001b). The activity of osteoclasts and osteoblasts can be monitored by measuring sensitive and specific circulating markers (Allen 2003). Classic markers for bone formation are bone-specific alkaline phosphatase (BALP) (Deftos et al. 1991), osteocalcin (OC) (Thiede et al. 1994), osteopontin (OPN) (Butler 1989, Sodek et al. 2000, Morinobu et al. 2003) and collagen propeptides (PICP,PINP) (Eberling et al. 1992), while serum and urinary levels of telopeptides of collagen type I (CTx, NTx), pyridinoline crosslinks (Pyd, Dpd) and tartrate-resistant acid phosphatase isoform 5b (TRAP5b) 
(Janckila et al. 2001) positively correlate with bone resorption, with high levels indicating excessive osteoclastic activity (Coleman 2002, Hanson et al. 1992).

In this context, the aim of the present study was to further elucidate the ER-subtype specific molecular mechanisms involved in bone protection. Therefore, OVX rats, a suitable animal model for studying processes underlying osteoporosis (Kalu 1991), were treated subcutaneously (s.c.) with ER subtype-specific agonists for ER $\alpha$ (16 $\alpha-$ LE2) or ERß (8$\beta-V E 2)$ over a period of three weeks. Intact (SHAM) animals, vehicletreated OVX animals on an isoflavone depleted diet (IDD) and OVX rats treated s.C. with $17 \beta$-estradiol $\left(E_{2}\right)$ served as controls.

To elucidate the mechanism(s) responsible for bone-protection by estrogens in vivo, bone mineral density (BMD) was measured by peripheral computed tomography (pQCT) and serum levels of several markers for bone formation (OC) and bone resorption (CTx, Pyd) as well as the extracellular glycoprotein OPN, secreted by osteoblasts, were assayed using commercial ELISA kits. 


\section{Material and Methods}

\section{Substances:}

17ß-Estradiol (Estra-1,3,5(10)-trien-3,16a,17 $\beta$-diol), was provided by Sigma-Aldrich (Deisenhofen, Germany). The specific estrogen receptor agonists for ERa (16 $\alpha$-LE2,

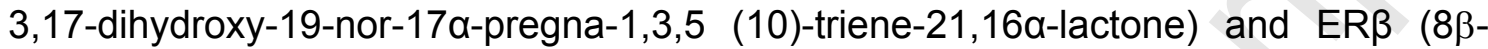
VE2, 8-vinylestra-1,3,5 (10)-triene-3,17 $\beta$-diol) (Fig.1) were provided by the Bayer Schering Pharma AG (Berlin, Germany) and the pure antiestrogen Faslodex (ICI 182,780 ) was provided by AstraZeneca (Wedel, Germany).

Diet:

Animals had free access to a diet low in phytoestrogen content (IDD) (SSniff GmbH, Soest, Germany) and water. The isoflavone contents of the IDD (Daidzein $<10 \mu \mathrm{g} / \mathrm{g}$, Genistein < 10 $\mathrm{gg} / \mathrm{g}$ ) have been determined by HPLC analysis in a previous study from our laboratory (Hertrampf et al. 2006).

\section{Animals:}

Female Wistar rats aged 8 weeks (125-150g) were obtained from Janvier (Janvier, Le Genest St Isle, France) and were maintained under controlled conditions of temperature $\left(20^{\circ} \mathrm{C} \pm 1\right.$, relative humidity $\left.50-80 \%\right)$ and illumination (12 h light, $12 \mathrm{~h}$ dark). All animal experiments were approved by the Committee on Animal Care and complied with accepted veterinary medical practice.

Animal treatment and tissue preparation:

Adult animals were ovariectomized (OVX) or SHAM operated at the age of 12 weeks, weighing 200-220g. After 14 days of endogenous hormonal decline the animals were 
treated with the test compounds or vehicle for 3 weeks. The animals were randomly allocated to treatment and vehicle groups $(n=6)$. $E_{2}\left(4 \mu g \mathrm{~kg}^{-1} \mathrm{~b} . \mathrm{wt} \mathrm{d}^{-1}\right), 16 \alpha-\mathrm{LE} 2$ $\left(10 \mu \mathrm{g} \mathrm{kg}{ }^{-1}\right.$ b.wt $\left.\mathrm{d}^{-1}\right)$ and $8 \beta$-VE2 $\left(100 \mu \mathrm{g} \mathrm{kg}{ }^{-1} \mathrm{~b} . \mathrm{wt} \quad \mathrm{d}^{-1}\right)$ were dissolved in dimethylsulfoxide (DMSO) $\left(200 \mu \mathrm{kg}^{-1}\right.$ b.wt d $\left.{ }^{-1}\right)$ and corn oil $\left(800 \mu \mathrm{kg}^{-1}\right.$ b.wt d $\left.{ }^{-1}\right)$ for s.c. administration. For isotype-specific ER activation, we used the selective ER-agonists 16 $\alpha$-LE2 and 8$\beta$-VE2 (Fig.1). Because these compounds activate both receptors at higher concentrations (Hegele-Hartung et al. 2004), doses of $10 \mu \mathrm{kg}^{-1} \mathrm{~b} . \mathrm{wt} \mathrm{d} \mathrm{d}^{-1}(16 \alpha-$ LE2) and $100 \mu \mathrm{gg}^{-1} \mathrm{~b} . w \mathrm{wt}^{-1}$ (8$\beta$-VE2) were chosen respectively. For these doses activation and subsequent signaling through either ER $\alpha$ or ER $\beta$ respectively can be anticipated (Hegele-Hartung et al. 2004, Hillisch et al. 2004). Animals were sacrificed by decapitation after light anesthesia with $\mathrm{CO}_{2}$ inhalation. Uteri were prepared free of fat and the wet weights were determined.

\section{Determination of bone mineral density}

The right tibiae were snap frozen in liquid nitrogen. BMD was measured by peripheral quantitative computed tomography (pQCT) (XCT Research SA+, StraTec Medizintechnik, Pforzheim, Germany). Trabecular density (measured by density mode, $\mathrm{ROI}$ at $7.5 \%$ of bone length), cortical density (ROI at $50 \%$ of bone length) and total density (ROI at $7.5 \%$ and $50 \%$ of bone length) of the tibiae were measured ex vivo at the end of the study after 3 weeks of treatment.

Quantification of bone markers

Serum concentrations of the bone formation marker osteocalcin (OC) (Thiede et al. 1994) were assayed using a commercial rat ELISA kit (Metra OC P, Quidel Corporation, San Diego, CA). 
Serum levels of telopeptides of CTx and Pyd, that correlate with bone resorption, with high levels indicating excessive osteoclastic activity (Coleman 2002, Hanson et al. 1992) were also analysed using commercial ELISA kits (Serum CrossLaps, Nordic Bioscience, Herlev, Denmark; Metra Serum Pyd, Quidel Corporation, San Diego, CA). OPN EDTA-plasma levels were also quantified by ELISA (Immuno-Biological Laboratories, Hamburg, Germany). All ELISAs were performed using a plate washer (HydroFlex Platform, Tecan GmbH, Crailsheim, Germany).

Statistical analysis

Statistical analyses were performed using the SPSS Statistical Analysis System, Version 12.0.

All data are expressed as arithmetic means with their standard errors. Statistical significance of differences was calculated using one-way analysis of variance (ANOVA) followed by a post hoc Tukey HSD test where appropriate. Statistical tests were used for comparisons between groups and statistical significance was established at $\mathrm{P}<0.05$. 


\section{Results}

OVX resulted in a reduction (6-fold) of uterine wet weights compared to SHAM animals (Fig.2 A). Treatment of OVX animals with 17ß-estradiol $\left(E_{2}\right)$ led to a stimulation of uterine wet weights (5-fold) relative to untreated OVX animals. In contrast to s.c. administration of $16 \alpha$-LE2 (4.5-fold), uterine wet weights were not affected by application of $8 \beta$-VE2 (Fig.2 A).

After 3 weeks, body weights of OVX animals were significantly elevated compared to SHAM animals (Fig.2 B). OVX-induced body weight gain could be antagonized by s.c. administration of $E_{2}$ and $16 \alpha-L E 2$, but was not significantly different to OVX in the group treated with 8 $\beta$-VE2 (Fig.2 B).

Trabecular BMD was significantly reduced in tibiae of OVX animals compared to intact (SHAM) rats (Fig.2 C). In contrast to application of $8 \beta$-VE2, s.c. administration of $E_{2}$ as well as treatment with $16 \alpha-L E 2$ over a period of three weeks equally resulted in an increased trabecular BMD compared to OVX (Fig.2 C).

Besides reduced trabecular BMD in the tibia, serum levels of the collagen degradation product CTX, was signifficantly elevated in OVX animals compared to SHAM animals (Fig. 3 B). However, the induced levels of the bone resorption marker Pyd detected in OVX animals were not significantly different from SHAM animals (Fig. $3 \mathrm{D}$ ). Moreover, serum levels of the bone formation markers (OC and OPN) were significantly higher in OVX animals (Fig. $3 \mathrm{~A}$ and $\mathrm{C}$ ). In line with $E_{2}$, but in contrast to treatment of OVX animals with $8 \beta$-VE2, application of $16 \alpha-L E 2$ resulted in significantly reduced serum levels of CTx, OC and OPN (Fig.3). Pyd serum levels tended to be reduced in SHAM and OVX animals treated with 16 $\alpha$-LE2 but 
significance was only observed in the group substituted with $E_{2}$ relative to vehicletreated OVX animals (Fig. 3 D). 


\section{Discussion}

The aim of the present study was to examine ER subtype-specific effects on bone mineral density (BMD) and expression patterns of certain markers for bone resorption and bone formation in adult female Wistar rats. OVX rats, a suitable animal model for studying processes underlying post-menopausal osteoporosis (Kalu 1991), were treated s.c. with ER subtype-specific agonists for ER $\alpha$ (16 $\alpha$-LE2) or ER $\beta$ (8$\beta$-VE2). Intact (SHAM) and OVX rats on an isoflavone depleted diet (IDD), and OVX animals substituted with $17 \beta$-estradiol $\left(E_{2}\right)$ served as controls.

The validity of our model system of menopause was confirmed by the analysis of classical biological endpoints for estrogenic action. For example, treatment with the respective compounds affected uterine wet weight in accordance with published literature (Pelzer et al. 2005, Hertrampf et al. 2007). 16 $\alpha$-LE2 stimulated uterine wet weights in a comparable manner to $E_{2}$ (Fig.2 A) (Hegele-Hartung et al. 2004) whereas treatment with $8 \beta-V E 2$ did not result in a significant stimulation of the uterine wet weight (Hillisch et al. 2004).

Elevated energy intake and increased body weight are both known to be associated with reduced levels of estrogens in OVX rats (Heine et al. 2000). In line with previous findings from our laboratory, our data shows that OVX rats display a stronger increase of body weight compared to $E_{2}$ and SHAM rats mainly due to an increase in the percentage of total body fat (Lindberg et al. 2001a, Hertrampf et al. 2007). In contrast to treatment with $8 \beta$-VE2, application of $16 \alpha-\mathrm{LE} 2$ resulted in an antagonization of body weight increase after OVX (Fig. 2 B). This is in agreement with studies using male and female ER $\alpha$ knockout mice (ERKO). In these animals lipid metabolism-related gene expression in adipose tissue and body fat composition are influenced by ER $\alpha$-specific signalling (Ohlsson et al 2000, Heine et al. 2000, 
Mueller et al. 2001). Our data demonstrate that the estrogen-dependent modulation of body weight and composition in wild type animals with natural ratios of both ER subtypes is also mainly mediated via ER $\alpha$ (Fig.2 B) (Lindberg et al. 2001a, Hertrampf et al. 2007).

According to previous findings from our laboratory, treatment with $16 \alpha-L E 2, E_{2}$ but not $8 \beta$-VE2 resulted in a significant increase of trabecular BMD compared to OVX animals (Fig.2 C), an effect that can be antagonized by the pure antiestrogen Fas (Hertrampf et al. 2007). These data are in agreement with studies performed in knockout mice: application of $E_{2}$ did not prevent the development of osteoporosis in ERaKO female (Lindberg et al. 2001a, Lindberg et al. 2002a) and male mice (Lindberg et al. 2002b), indicating that the bone-protective effects of $E_{2}$ are primarily mediated by ER $\alpha$. Further, ERa gene polymorphisms are associated with osteoporosis in human populations (Gómez et al. 2007).

On the other hand differentiation of bone marrow cells lacking ERa, can be stimulated by $E_{2}$ relatively to the same extent as in wild type cells (Parikka et al. 2005), indicating ERß to be involved in bone marrow cell differentiation. Opposing effects were observed for longitudinal bone growth after activation of ER $\alpha$ and ER $\beta$ (Windahl et al. 1999, Lindberg et al. 2001a), suggesting a repressive function for ER $\beta$ in the regulation of bone growth during adolescence.

Because the impact of the two ER subtypes on bone metabolism is not fully understood, this study aimed to examine the impact of ER subtype-specific agonists on physiological serum markers of bone resorption and bone formation.

All tested serum markers were significantly elevated in OVX compared to SHAM and $E_{2}$ animals (Fig.3). In the OVX group substituted with $16 \alpha$-LE2, serum levels of OC, 
OPN and CTx were significantly lower than in the OVX group, while Pyd levels only tended to be reduced (Fig.3).

$\mathrm{OC}$, one of the very few molecules exclusively produced by osteoblasts, is a widely used marker for bone formation (Lerner 2006). In postmenopausal osteoporosis bone resorption as well as bone formation are increased (Lerner 2006). In line with this are our current findings showing that both bone formation markers like OC and OPN as well as excretion levels of collagen degradation products (CTx, Pyd) are elevated in OVX rats compared to SHAM animals, and decreased in OVX animals treated with $E_{2}$ and $16 \alpha$-LE2 (Fig.3). In contrast to treatment with $E_{2}$ and $16 \alpha$-LE2, neither serum levels of OC and OPN nor those of CTx and Pyd were affected by $8 \beta$-VE2 application compared to OVX (Fig.3). These results indicate that the activation of ERa is mainly responsible for the estrogenic stimulatory effects on osteoblastic bone-formation and inhibitory effects on osteoclastic bone-resorption. This observation agrees with the results of Lindberg et al. (2001b) showing that ERa but nor ER $\beta$ is involved in the regulation of the OPG/RANKL ratio and serum levels of interleukin-6 (IL-6) and tartrate-resistant acid phosphatase 5b (TRAP5b). Moreover, it was shown that estrogens regulate the life span of mature osteoclasts by inducing apoptosis via ERa (Nakamura et al. 2007), and that ERa is required for proliferation of osteoblast-like cells in vitro (Lee et al. 2003).

Taken together, the trabecular BMD data of the present study and the complex secretion patterns of certain markers for bone-resorption and bone-formation indicate that, in contrast to $8 \beta$-VE2, $16 \alpha$-LE2 mediates bone-protective effects by inhibiting OPN and OC secretion in osteoblasts. In addition to reduced OC and OPN serum levels, application of $16 \alpha$-LE2 but not $8 \beta$-VE2 resulted in an inhibition of boneresorption, represented by reduced serum levels of CTx and Pyd. 
The results of the present study lead us to the conclusion that bone-resorption by osteoclasts and bone-formation by osteoblasts are both influenced by estrogens and estrogenic compounds via ERa but not ERß. Further studies should be conducted to elucidate if ERß antagonizes ERa-specific signalling in bone or is more likely responsible for bone cell differentiation. 


\section{Literature}

Allen, M.J., 2003. Biochemical markers of bone metabolism in animals: uses and limitations. Vet Clin Pathol. 32(3):101-13. Review.

Blair, J.M., Zheng, Y., Dunstan, C.R., 2007. RANK ligand. Int. J. Biochem. Cell. Biol. 39(6):1077-81. Review.

Bland, R., 2000. Steroid hormone receptor expression and action in bone. Clin. Sci. (Lond). 98(2):217-40. Review.

Bord, S., Horner, A., Beavan, S., Compston, J., 2001. Estrogen receptors alpha and beta are differentially expressed in developing human bone. J. Clin. Endocrinol. Metab. 86(5):2309-14.

Bryant, H.U., Glasebrook, A.L., Yang, N.N., Sato, M., 1999. An estrogen receptor basis for raloxifene action in bone. J. Steroid. Biochem. Mol. Biol. 69(1-6):37-44. Review.

Buckwalter, J.A., Glimcher, M.J., Cooper, R.R., Recker, R. 1996. Bone biology. II: Formation, form, modeling, remodeling, and regulation of cell function. Instr. Course Lect. 45:387-99. Review.

Butler, W.T., 1989. The nature and significance of osteopontin. Connect. Tissue Res. 23(2-3):123-36. Review. 
Coleman, R.E., 2002. The clinical use of bone resorption markers in patients with malignant bone disease. Cancer. 94(10):2521-33. Review.

Deftos, L.J., Wolfert, R.L., Hill, C.S., 1991. Bone alkaline phosphatase in Paget's disease. Horm. Metab. Res. 23(11):559-61.

Diez-Perez, A., 2006. Selective estrogen receptor modulators (SERMS). Arq. Bras. Endocrinol. Metabol. 50(4):720-34.

Diez, J.L., 2000. Skeletal effects of selective oestrogen receptor modulators (SERMs). Hum. Reprod. Update. 6(3):255-8. Review.

Ebeling, P.R., Peterson, J.M., Riggs, B.L., 1992. Utility of type I procollagen propeptide assays for assessing abnormalities in metabolic bone diseases. J. Bone Miner. Res. 7(11):1243-50.

Fitzpatrick, L.A., 2006. Estrogen therapy for postmenopausal osteoporosis. Arq. Bras. Endocrinol. Metabol. 50(4):705-19. Review.

Girasole, G., Jilka, R.L., Passeri, G., Boswell, S., Boder, G., Williams, D.C., Manolagas, S.C., 1992. 17 beta-estradiol inhibits interleukin-6 production by bone marrow-derived stromal cells and osteoblasts in vitro: a potential mechanism for the antiosteoporotic effect of estrogens. J. Clin. Invest. 89(3):883-91.

Gómez, R., Magaña, J.J., Cisneros, B., Pérez-Salazar, E., Faugeron, S., Véliz, D., Castro, C., Rubio, J., Casas, L., Valdés-Flores, M., 2007. Association of the estrogen 
receptor alpha gene polymorphisms with osteoporosis in the Mexican population.

Clin. Genet. 72(6):574-81.

Hadjidakis, D.J., Androulakis, I.I., 2006. Bone remodeling. Ann. N. Y. Acad. Sci. 1092:385-96. Review.

Hamdy, N.A., 2007. Targeting the RANK/RANKL/OPG signaling pathway: a novel approach in the management of osteoporosis. Curr. Opin. Investig. Drugs. 8(4):299303. Review.

Hanson, D.A., Weis, M.A., Bollen, A.M., Maslan, S.L., Singer, F.R., Eyre, D.R., 1992. A specific immunoassay for monitoring human bone resorption: quantitation of type I collagen cross-linked N-telopeptides in urine. J. Bone. Miner. Res. 7(11):1251-8.

Hegele-Hartung, C., Siebel, P., Peters, O., Kosemund, D., Muller, G., Hillisch, A., Walter, A., Kraetzschmar, J., Fritzemeier, K.H., 2004. Impact of isotype-selective estrogen receptor agonists on ovarian function. Proc. Natl. Acad. Sci. U S A. 101(14), 5129-34.

Heine, P.A., Taylor, J.A., Iwamoto, G.A., Lubahn, D.B., Cooke, P.S., 2000. Increased adipose tissue in male and female estrogen receptor-alpha knockout mice. Proc. Natl. Acad. Sci. U S A. 97(23), 12729-34.

Hertrampf, T., Degen, G.H., Kaid, A.A., Laudenbach-Leschowsky, U., Seibel, J., Di Virgilio, A.L., Diel, P., 2006. Combined effects of physical activity, dietary isoflavones 
and 17beta-estradiol on movement drive, body weight and bone mineral density in ovariectomized female rats. Planta Med. 72(6):484-7.

Hertrampf, T., Gruca, M.J., Seibel, J., Laudenbach, U., Fritzemeier, K.H., Diel, P., 2007. The bone-protective effect of the phytoestrogen Genistein is mediated via ERa-dependent mechanisms and strongly enhanced by physical activity. Bone 40(6):1529-35.

Hillisch, A., Peters, O., Kosemund, D., Muller, G., Walter, A., Schneider, B., Reddersen, G., Elger, W., Fritzemeier, K.H., 2004. Dissecting physiological roles of estrogen receptor alpha and beta with potent selective ligands from structure-based design. Mol. Endocrinol. 18(7), 1599-609.

Janckila, A.J., Takahashi, K., Sun, S.Z., Yam, L.T., 2001. Tartrate-resistant acid phosphatase isoform $5 \mathrm{~b}$ as serum marker for osteoclastic activity. Clin. Chem. 47(1):74-80.

Jordan, V.C., 2008. Tamoxifen: Catalyst for the change to targeted therapy. Eur. J. Cancer. 44(1):30-8.

Kalu, D.N., 1991. The ovariectomized rat model of postmenopausal bone loss. Bone Miner. 15(3), 175-91. Review.

Krassas, G.E, Papadopoulou, P., 2001. Oestrogen action on bone cells. J. Musculoskelet. Neuronal Interact. 2(2):143-51. 
Lee, K., Jessop, H., Suswillo, R., Zaman, G., Lanyon, L., 2003. Endocrinology: bone adaptation requires oestrogen receptor-alpha. Nature. 424(6947):389.

Lerner, U.H., 2006. Bone remodeling in post-menopausal osteoporosis. J. Dent. Res. 85(7):584-95. Review.

Lindsay, R., Hart, D.M., Aitken, J.M., MacDonald, E.B., Anderson, J.B., Clarke, A.C., 1976. Long-term prevention of postmenopausal osteoporosis by oestrogen. Evidence for an increased bone mass after delayed onset of oestrogen treatment. Lancet. 1(7968):1038-41.

Lindberg, M.K., Alatalo, S.L., Halleen, J.M., Mohan, S., Gustafsson, J.A., Ohlsson, C., 2001a. Estrogen receptor specificity in the regulation of the skeleton in female mice. J. Endocrinol. 171(2), 229-36.

Lindberg, M.K., Erlandsson, M., Alatalo, S.L., Windahl, S., Andersson, G., Halleen, J.M., Carlsten, H., Gustafsson, J.A., Ohlsson, C., 2001b. Estrogen receptor alpha, but not estrogen receptor beta, is involved in the regulation of the OPG/RANKL (osteoprotegerin/receptor activator of NF-kappa B ligand) ratio and serum interleukin6 in male mice. J. Endocrinol. 171(3):425-33.

Lindberg, M.K., Weihua, Z., Andersson, N., Movérare, S., Gao, H., Vidal, O., Erlandsson, M., Windahl, S., Andersson, G., Lubahn, D.B., Carlsten, H., DahlmanWright, K., Gustafsson, J.A., Ohlsson, C., 2002a. Estrogen receptor specificity for the effects of estrogen in ovariectomized mice. J. Endocrinol. 174(2):167-78. 
Lindberg, M.K., Moverare, S., Skrtic, S., Alatalo, S., Halleen, J., Mohan, S.,

Gustafsson, J.A., Ohlsson, C., 2002b. Two different pathways for the maintenance of trabecular bone in adult male mice. J. Bone Miner. Res. 17(4), 555-62.

Morinobu, M., Ishijima, M., Rittling, S.R., Tsuji, K., Yamamoto, H., Nifuji, A.,

Denhardt, D.T., Noda, M., 2003. Osteopontin expression in osteoblasts and osteocytes during bone formation under mechanical stress in the calvarial suture in vivo. J. Bone Miner. Res. 18(9):1706-15.

Mueller, S.O., Korach, K.S., 2001. Estrogen receptors and endocrine diseases: lessons from estrogen receptor knockout mice. Curr. Opin. Pharmacol. 1(6), 613-9. Review.

Nakamura, T., Imai, Y., Matsumoto, T., Sato, S., Takeuchi, K., Igarashi, K., Harada, Y., Azuma, Y., Krust, A., Yamamoto, Y., Nishina, H., Takeda, S., Takayanagi, H., Metzger, D., Kanno, J., Takaoka, K., Martin, T.J., Chambon, P., Kato, S., 2007. Estrogen prevents bone loss via estrogen receptor alpha and induction of Fas ligand in osteoclasts. Cell. 7;130(5):811-23.

Parikka, V., Peng, Z., Hentunen, T., Risteli, J., Elo, T., Väänänen, H.K., Härkönen, P., 2005. Estrogen responsiveness of bone formation in vitro and altered bone phenotype in aged estrogen receptor-alpha-deficient male and female mice. Eur. J. Endocrinol. 152(2):301-14.

Pelzer, T., Jazbutyte, V., Hu, K., Segerer, S., Nahrendorf, M., Nordbeck, P., Bonz, A.W., Muck, J., Fritzemeier, K.H., Hegele-Hartung, C., Ertl, G., Neyses, L., 2005. The 
estrogen receptor-alpha agonist 16alpha-LE2 inhibits cardiac hypertrophy and improves hemodynamic function in estrogen-deficient spontaneously hypertensive rats. Cardiovasc. Res. 67(4), 604-12.

Ohlsson, C., Hellberg, N., Parini, P., Vidal, O., Bohlooly, M., Rudling, M., Lindberg, M.K., Warner, M., Angelin, B., Gustafsson, J.A., 2000. Obesity and disturbed lipoprotein profile in estrogen receptor-alpha-deficient male mice. Biochem. Biophys. Res. Commun. 278(3), 640-5.

Sato, T., Shibata, T., Ikeda, K., Watanabe, K., 2001. Generation of bone-resorbing osteoclasts from B220+ cells: its role in accelerated osteoclastogenesis due to estrogen deficiency. J. Bone Miner. Res. 16(12):2215-21.

Sodek, J., Ganss, B., McKee, M.D., 2000. Osteopontin. Crit. Rev. Oral. Biol. Med.11(3):279-303. Review.

Sorensen, M.G., Henriksen, K., Dziegiel, M.H., Tanko, L.B., Karsdal, M.A., 2006. Estrogen directly attenuates human osteoclastogenesis, but has no effect on resorption by mature osteoclasts. DNA Cell. Biol. 25(8):475-83.

Stevenson, J.C., 2004. Hormone replacement therapy: review, update, and remaining questions after the Women's Health Initiative Study. Curr. Osteoporos. Rep. 2(1):12-6. Review.

Syed, F.A., Mödder, U.I., Fraser, D.G., Spelsberg, T.C., Rosen, C.J., Krust, A., Chambon, P., Jameson, J.L., Khosla, S., 2005. Skeletal effects of estrogen are 
mediated by opposing actions of classical and nonclassical estrogen receptor pathways. J. Bone Miner. Res. 20(11):1992-2001.

Taranta, A., Brama, M., Teti, A., De luca, V., Scandurra, R., Spera, G., Agnusdei, D., Termine, J.D., Migliaccio, S., 2002. The selective estrogen receptor modulator raloxifene regulates osteoclast and osteoblast activity in vitro. Bone. 30(2):368-76.

Thiede, M.A., Smock, S.L., Petersen, D.N., Grasser, W.A., Thompson, D.D., Nishimoto, S.K., 1994. Presence of messenger ribonucleic acid encoding osteocalcin, a marker of bone turnover, in bone marrow megakaryocytes and peripheral blood platelets. Endocrinology. 135(3):929-37.

Windahl, S.H., Vidal, O., Andersson, G., Gustafsson, J.A., Ohlsson, C., 1999. Increased cortical bone mineral content but unchanged trabecular bone mineral density in female ERbeta(-/-) mice. J. Clin. Invest. 104(7):895-901.

Zaman, G., Cheng, M.Z., Jessop, H.L., White, R., Lanyon, L.E., 2000. Mechanical strain activates estrogen response elements in bone cells. Bone. 27(2):233-9. 
Fig.:1

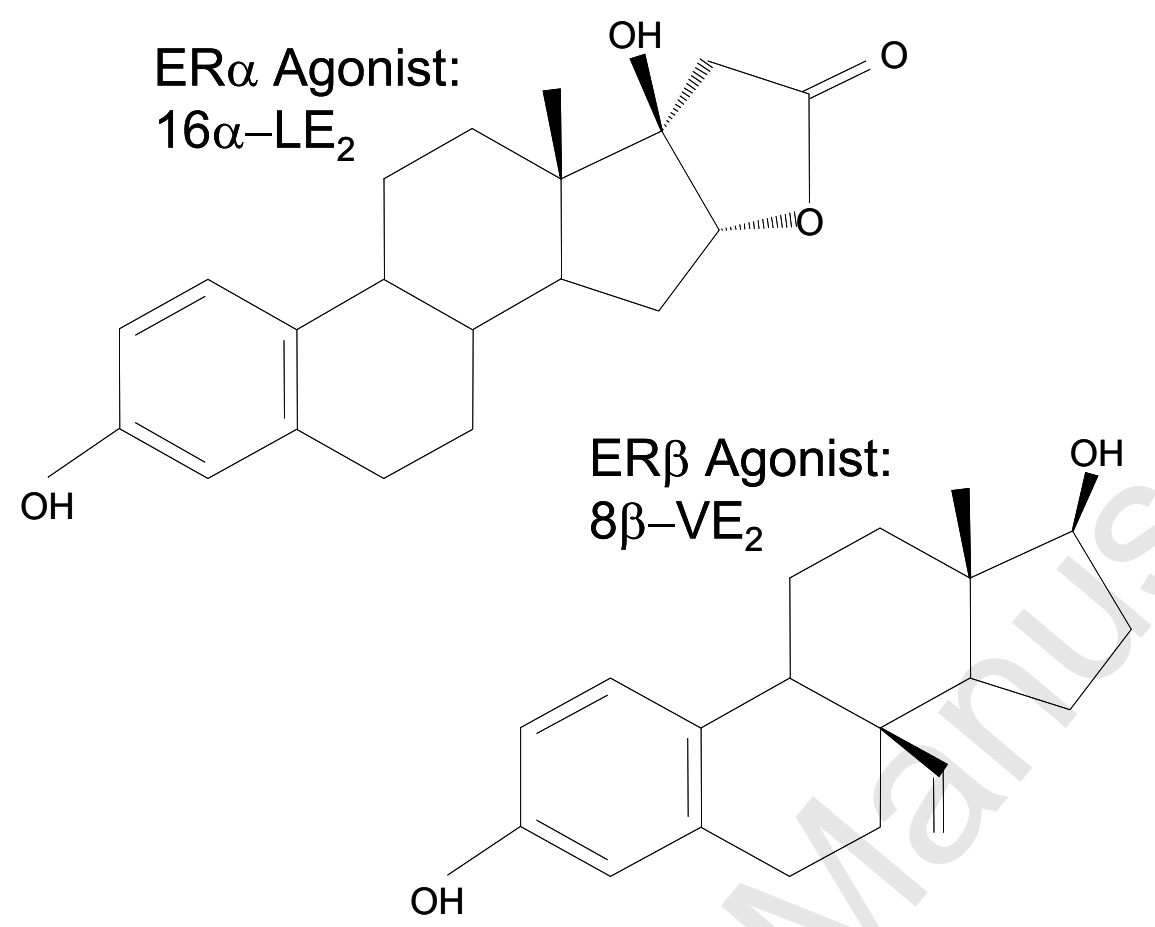


Fig.:2
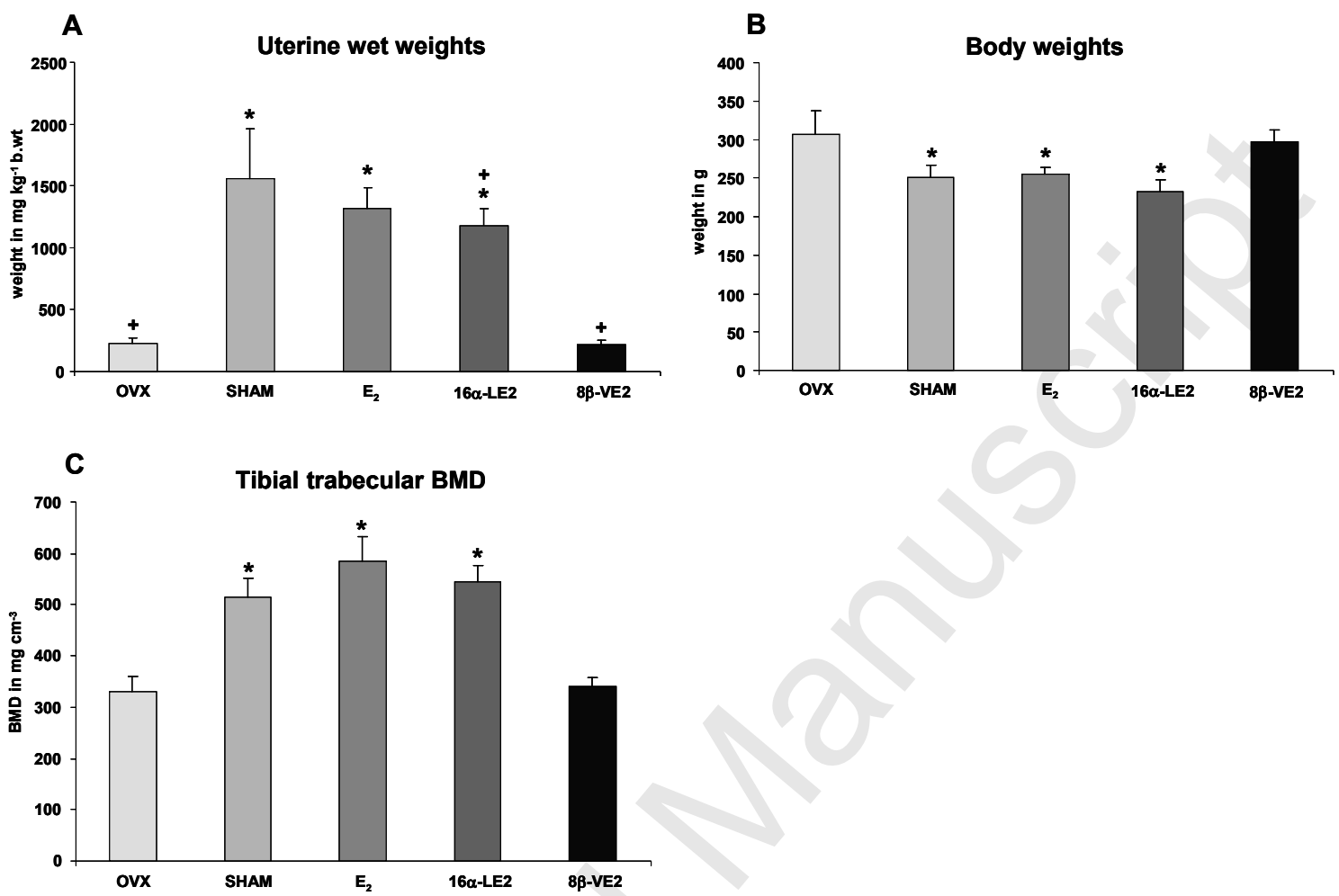


\section{Fig.:3}
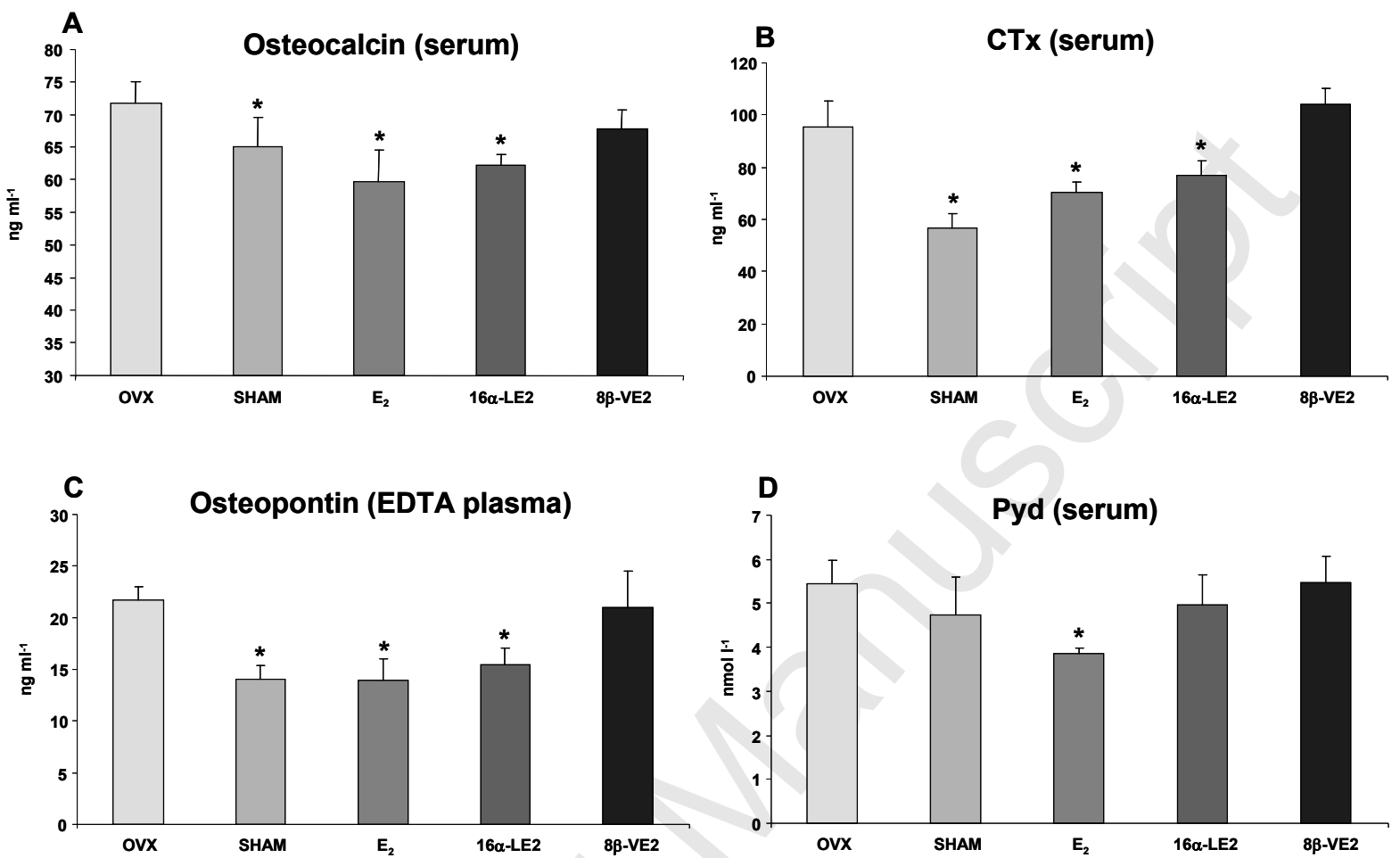


\section{Figure legends}

Fig.1 ER subtype-specific agonists.

Chemical structures of the specific ER agonists for ERa: $16 \alpha-L_{2}$ and ER $\beta$ : $8 \beta-V E_{2}$.

Fig.2 Physiological end points.

Uterine wet weights (A), Body weights $(B)$ and trabecular bone mineral density (C) after 3 weeks of treatment.

Abbreviations: SHAM = intact, SHAM operated animals fed IDD, $E_{2}=$ OVX group treated s.c. with $17 \beta$ - estradiol $\left(4 \mu \mathrm{kg}^{-1} \mathrm{~b} . \mathrm{wt} \mathrm{d}^{-1}\right)$, OVX $=$ vehicle-treated OVX group fed IDD, $16 \alpha-\mathrm{LE}_{2}=$ OVX group treated s.c. with $16 \alpha-\mathrm{LE}_{2}\left(10 \mu \mathrm{gg}^{-1} \mathrm{~b} . \mathrm{wt} \mathrm{d}^{-1}\right), 8 \beta-\mathrm{VE}_{2}$ $=$ OVX group treated s.c. with $8 \beta-\mathrm{VE}_{2}\left(100 \mu \mathrm{g} \mathrm{kg}{ }^{-1} \mathrm{~b} . \mathrm{wt} \mathrm{d}^{-1}\right)$. Experimental conditions and treatment procedures are explained in detail in Materials and Methods.

* Denotes values significantly different from ovariectomized group (OVX) $\mathrm{P}<=0.05$, ANOVA, $\mathrm{n}=6$

+ Denotes values significantly different from intact group (SHAM) $\mathrm{P}<=0.05$, ANOVA, $\mathrm{n}=6$ 
Fig.3 Bone markers.

Abbreviations: SHAM $=$ intact, SHAM operated animals fed IDD, $E_{2}=\mathrm{OVX}$ group treated s.c. with $17 \beta$ - estradiol $\left(4 \mu \mathrm{kg}^{-1} \mathrm{~b} \cdot \mathrm{wt}^{-1}\right), \mathrm{OVX}=$ vehicle-treated OVX group fed IDD, $16 \alpha-L E_{2}=$ OVX group treated s.c. with $16 \alpha-\mathrm{LE}_{2}\left(10 \mu \mathrm{kg}^{-1} \mathrm{~b} . \mathrm{wt} \mathrm{d}^{-1}\right), 8 \beta-\mathrm{VE}_{2}$ $=\mathrm{OVX}$ group treated s.c. with $8 \beta-\mathrm{VE}_{2}\left(100 \mu \mathrm{g} \mathrm{kg}{ }^{-1} \mathrm{~b} \cdot \mathrm{wt} \mathrm{d}^{-1}\right)$. Experimental conditions and treatment procedures are explained in detail in Materials and Methods.

* Denotes values significantly different from ovariectomized group (OVX)

$\mathrm{P}<=0.05$, ANOVA, $\mathrm{n}=6$ 